\title{
Konjenital Sitomegalovirüs Enfeksiyonlarının Tanı ve Yönetiminde Güncel Yaklaşımlar ve Türkiye'deki Durum
}

\section{Current Approaches in the Diagnosis and Management of Congenital Cytomegalovirus Infections and the Situation in Turkey}

\author{
Fatih ŞAHINER ${ }^{1}(\mathrm{IID})$ \\ 1 Sağlık Bilimleri Üniversitesi Gülhane Tıp Fakültesi, Tıbbi Mikrobiyoloji Anabilim Dalı, Ankara. \\ ${ }^{1}$ Health Sciences University Faculty of Gulhane Medicine, Department of Medical Microbiology, Ankara, Turkey.
}

Makale Atıfı: Şahiner F. Konjenital sitomegalovirüs enfeksiyonlarının tanı ve yönetiminde güncel yaklaşımlar ve Türkiye'deki durum. Mikrobiyol Bul 2020;54(1):171-190.

\section{ÖZ}

İnsan sitomegalovirüs (CMV) enfeksiyonları tüm toplumlarda yaygındır ve dünya genelinde doğurganlık çağındaki kadınlarda CMV seroprevalansı \%45-100 aralığındadır. CMV konjenital enfeksiyonların en sık nedenidir ve fetal gelişim defektleri ve işitme kaybı ile ilişkilidir. Konjenital enfeksiyon gelişme riski maternal immünite ile doğrudan ilişkili olup primer olan ve olmayan enfeksiyonlarda görülme sıklı̆ı̆ sırasıyla \%30-40 ve \%1-2'dir. Konjenital enfeksiyonlu bebeklerin sadece \%5-10'u doğumda semptomatiktir. Bu bebeklerin \%4'üne yakınında erken dönemde ölüm görülürken, \%40-60'ı yaşamlarını sensörinöral işitme kaybı, kognitif bozukluk ve görme bozukluğu gibi kalıcı sekellerle sürdürmek zorunda kalmaktadır. Primer enfeksiyonu olmayan annelerden doğanlar da dahil olmak üzere asemptomatik bebekler de uzun dönem boyunca sekeller açısından risk altındadırlar. Bu sekeller sıklıkla yaşamın ilk 1-2 yılı içerisinde gelişmekle birlikte, risk 5-7 yıla kadar uzayabilmekte, ancak hasar şiddeti azalmaktadır. Türkiye'de doğurganlık çağındaki kadınlarda ve gebelerde CMV seroprevalansı \%96-99.8 düzeylerindedir. Türkiye'de yakın zamana kadar konjenital CMV enfeksiyonlarının sıklı̆̆ı ile ilgili bilgilerimiz maternal taramaları temel alan çalışmalara dayanmaktaydı. Konjenital CMV enfeksiyonlarının gerçek prevalansını yansıtmaktan uzak olan bu çalışmaların yerini, yenidoğan bazıı sistematik tarama çalışmaları almaya başlamıştır. Türkiye'de yapılan yenidoğan tarama çalışmalarında tükürük örneklerinde CMV DNA pozitifliği \%1.6-1.9 olarak saptanmış, tükürük örneği ile beraber idrar ve/veya kan örneklerinde pozitiflik görülme oranı ise \%0.2-1.4 olarak bulunmuştur. Türkiye'deki yenidoğanlarda en sık saptanan CMV genotipi glikoprotein B-1 (gB1) (\%38.4-83.3) olarak bulunmuştur. Onaylı bir aşının olmaması ve mevcut aşıların düşük koruyuculuğu, maternal ve konjenital enfeksiyonların önlenmesinde anne eğitimi, gebelerin virüs saçan çocuklarla temasının azaltılması, el hijyeni gibi standart önlemleri ve koruyucu halk sağlığı uygulamalarını öne çıkarmıştır. Özellikle immün yetmezliği olan kişiler için kan ürünlerinin taranması ve in vitro fertilizasyon uygulamalarında serolojik tarama yapılması gibi ileri düzey önlemler de değerlendirilmektedir. Enfekte bebeklerin ve annelerinin gebelik sürecinde takibi, doğum sonrası tanı 
ve ebeveynlere danışmanlık hizmeti sunulması kritik öneme sahiptir. Her yenidoğan için rutin bir uygulama haline gelen tarama testleri ile işitme kaybı erken dönemde saptanabilmektedir. Böylece konuşma terapisi ve işitme cihazlarının kullanımı gibi uygulamalar ile enfeksiyondan etkilenen çocukların bilişsel ve psikososyal gelişimi desteklenmektedir. Bununla birlikte, enfekte bebeklerde işitme fonksiyonlarının doğum esnasında normal olabileceği, ancak bu bebeklerin ilerleyici sensörinöral işitme kaybı için risk altında olduğu dikkate alınmalıdır. Asemptomatik bebeklerin erken tanısı için CMV testlerinin yenidoğan tarama programlarının bir parçası haline gelmesi önemlidir. Bir diğer koruyucu yaklaşım, anne ve bebeğin doğrudan virüsü hedefleyen antiviral ilaç ve preparatlarla tedavi edilmesidir. Gebelerin pasif immünizasyonu ve semptomatik bebeklerde valgansiklovir tedavisiyle olumlu sonuçlar alınmıştır. Bu derleme yazıda, konjenital CMV enfeksiyonlarının tanı ve takibinde kullanılan maternal, fetal ve yenidoğan temelli güncel yaklaşımlar tartışılmıştır.

Anahtar kelimeler: Sitomegalovirüs; fetüs; işitme kaybı; yenidoğan.

\section{ABSTRACT}

Human cytomegalovirus (CMV) infections are common in all populations and CMV seroprevalence in women of childbearing age is in the range of $45-100 \%$ worldwide. CMV is the most common cause of congenital infections and is associated with fetal development defects and hearing loss. The risk of congenital infection is directly related to maternal immunity and is between $30-40 \%$ and $1-2 \%$ range in primary and non-primary infections, respectively. Only 5-10\% of newborns with congenital infection are symptomatic at birth. Nearly $4 \%$ of these babies can die early in life, while $40-60 \%$ have to live with permanent sequelae such as sensorineural hearing loss, cognitive deficit and visual impairment. Asymptomatic newborns including those born from mothers with non-primary infections are also at risk for long-term sequelae. These sequelae often develop in the first 1-2 years of life and may extend up to 5-7 years, but the severity of damage reduces in time. CMV seroprevalence in women of childbearing age and pregnant women in Turkey is between $96 \%$ and $99.8 \%$. Until recently, our knowledge about the frequency of congenital CMV infections in Turkey was derived from the studies based on the maternal screening tests. These studies, which were far from reflecting the true prevalence of congenital CMV infections, have begun to be replaced by newborn-based systematic screening studies. CMV DNA positivity was found to be $1.6-1.9 \%$ in saliva samples, while both saliva and urine and/or blood samples positivity was found to be $0.2-1.4 \%$ in the newborn screening studies carried out in Turkey. Glycoprotein B-1 (gB1) was the most frequently detected genotype (38.4-83.3\%) in newborns in Turkey. Standard measures and preventive public health practices such as education of the mother, reducing the contact of pregnant women with virus-spreading children and the hand hygiene come into prominence in the prevention of maternal and congenital infections as a result of the absence of an approved vaccine or low protection of existing vaccines. Advanced measures, such as screening blood products especially for the people with immunodeficiency and serological screening of the in-vitro fertilization applications are also being considered. Monitoring of infected newborns and their mothers during pregnancy, postnatal diagnosis and providing counseling for the parents are also critical. Hearing loss can be detected at an early stage using screening tests that become a routine practice for all newborns. Thus, cognitive and psychosocial development of children affected by infection is supported by speech therapy, the use of hearing aids and other practices. However, it should be noted that hearing functions in infected newborns may be normal at birth, but these newborns are at risk for progressive sensorineural hearing loss. For early diagnosis of asymptomatic newborns, it is important to adopt CMV tests as a part of newborn screening programs. Another preventive approach is to treat the mother and the baby with antiviral drugs and preparations that directly target the virus. Passive immunization of the pregnant and the treatment of the symptomatic newborns with valganciclovir have yielded positive results. In this review article, maternal, fetal and newborn based current approaches used in the diagnosis and follow-up of congenital CMV infections have been discussed.

Keywords: Cytomegalovirus; fetus; hearing loss; newborn. 


\section{Gíriş}

Herpesviridae ailesinde yer alan insan sitomegalovirüs (CMV) enfeksiyonları dünya genelinde tüm toplumlarda yaygın olup, gelişmekte olan ülkelerde çoğu birey CMV ile erken çocukluk döneminde karşılaşmaktadır ${ }^{1-3}$. Primer CMV enfeksiyonu tükürük, idrar, süt ve genital sekresyonlarda virüs atılımı ile seyreden aktif viral replikasyon periyodu, viremik faz ve bazı olgularda da mononükleoz sendrom benzeri enfeksiyon tablosuyla karakterizedir ${ }^{4}$. Enfeksiyon çoğu bireyde asemptomatik olarak geçirilir, bununla birlikte, CMV hem bağışıkık defekti olan kişilerde hem de konjenital enfeksiyonlu olgularda mortalite ve morbiditenin önemli bir nedenidir ${ }^{1}$. CMV başlıca oral sekresyonları veya idrarlarında virüs saçan çocuk ve erişkinlerin vücut sıvılarıyla temas, cinsel aktivite, kan transfüzyonu ve organ transplantasyonu ile bulaşmaktadır ${ }^{5-7}$. Enfekte anneden bebeğe transplasental yol veya emzirme ile de bulaşabilen CMV dünya genelinde önde gelen bir konjenital enfeksiyon etkenidir ve günümüzde çocuklarda santral sinir sistemi (SSS) hastalı̆̆ı ve işitme kaybının en önemli enfeksiyöz nedenidir ${ }^{4,8}$. Gelişmiş ülkelerde tüm işitme kaybı olgularının doğumda \%21'inin, dört yaşında \%24'ünün konjenital CMV ile ilişkili olduğu tahmin edilmektedir ${ }^{4}$.

Konjenital CMV enfeksiyonları annenin gebelik esnasında geçirdiği aktif enfeksiyonlar (primer enfeksiyon, reaktivasyon ve farklı bir virüs kökeni ile yeni enfeksiyon) sırasında virüsün uterin ve plasental kompartımanlarda çoğalması ve fetüse geçişi ile meydana gelmektedir ${ }^{5,9,10}$. Konjenital CMV enfeksiyonlarının toplum sağlığı açısından önemi, görülme sıkığı ve enfekte çocukların önemli bir kısmında ortaya çıkan nörogelişimsel bozukluklara atfedilmektedir. Konjenital enfeksiyonlu bebeklerin sadece \%5-10'u doğduğunda semptomatik iken geri kalanı asemptomatiktir ${ }^{1,11,12}$. Semptomatik bebekler enfeksiyon komplikasyonları yüzünden hayatın erken dönemlerinde ölebilirler (4\%), ancak bu bebeklerin çoğunluğu (\%40-60) hayatlarını nörolojik hasarlarla birlikte sürdürmek durumunda kalırlar ${ }^{12,13}$. Semptomatik bebeklerde uzun dönem sekellerin görülme sıklığı; sensörinöral işitme kaybı \%35, mental retardasyon-kognitif bozukluk üçte ikisine kadar, görme bozuklukları \%22-58 şeklindedir ${ }^{4,12}$. Enfekte bebeklerin çoğunluğunu oluşturan asemptomatik yenidoğanlarda doğumdan hemen sonraki dönemde herhangi bir nörolojik bozukluk görülmese de, bu bebeklerin \%8-15'inde uzun dönemde nörolojik sekeller (işitsel kayıp başta olmak üzere, mental retardasyon ve görsel kayıp) gelişebilmektedir $4,5,12,14$. Uzun dönem sekeller sıklıkla yaşamın ilk 1-2 ylında ortaya çıkarken, 5-7 yıla kadar uzayan dönemde orta düzey bozukluklar görülebilmektedir ${ }^{12}$. Bu derleme yazıda konjenital CMV enfeksiyonlu olguların tanısı, izlemi ve tedavisinde karşılaşılan problemler ve güncel uygulamalar ile ülkemizde yapılan çalışmalara ait veriler tartışılıı̧ı̧ır.

\section{Sitomegalovirüs Epidemiyolojisi ve Türkiye'deki Durum}

CMV enfeksiyonları tüm toplumlarda yaygındır, ancak seroprevalansı ülkelere ve bölgelere göre önemli ölçüde farklılıklar göstermektedir. Dünya genelinde doğurganlık çağındaki kadınlarda seropozitiflik oranları \%45-100 aralığındadır³. Türkiye CMV seroprevalansının en yüksek olduğu ülkelerden biri iken, İrlanda, Kanada, Almanya ve Birleşik 
Krallık bu oranın düşük olduğu ülkelerdir ${ }^{3}$. Türkiye'de yapılan birkaç çalışmada bölgesel ve dönemsel olarak daha düşük oranlar bulunmuş olsa da, kapsamlı çalışmalardan elde edilen veriler gebelerde CMV seropozitifliğinin genel olarak \%96-99.8 aralığında olduğunu göstermektedir ${ }^{15-17}$ (Tablo I).

Kapsamlı çalışmalardan elde edilen veriler günümüzde çocuklarda nörolojik yıkımın en önde gelen enfeksiyon etkeni olan konjenital CMV enfeksiyonunun, dünya genelindeki prevalansının \%0.2-2.2 aralığında olduğunu göstermektedir6,11. Konjenital CMV enfeksiyonu görülme sıklı̆̆ gelişmekte olan ülkelerde daha yüksek iken, gelişmiş ülkelerde düşük gelir gruplarında yüksek prevalans görülmektedir ${ }^{4,6}$. Siyahi ırk, düşük sosyoekonomik durum, prematüre doğum ve yenidoğan yoğun bakım ünitesinde yatmanın konjenital CMV enfeksiyonu için risk faktörleri olduğu bildirilmiştir ${ }^{11}$. Türkiye'de konjenital CMV enfeksiyonu prevalansına dair bilgilerimiz yakın zamana kadar genel olarak iki gruba ayırabileceğimiz az sayıdaki çalışma verilerine dayanmaktaydı. Birinci grup çalışmalar serolojik veya moleküler testlerle maternal örneklerde enfeksiyon göstergelerinin tarandığı ve şüpheli sonuçlara ulaşıldığında fetüste veya yenidoğanda enfeksiyon varlı-

\begin{tabular}{|c|c|c|c|c|}
\hline Çalışmalar & Çalışma grubu & $\begin{array}{l}\text { CMV IgM } \\
\text { pozitifliği }\end{array}$ & $\begin{array}{l}\text { CMV IgG } \\
\text { pozitifliği }\end{array}$ & $\begin{array}{l}\text { IgG avidite } \\
\text { sonuçları }\end{array}$ \\
\hline İzmir, $2012^{18}$ & Gebe & $\% 0.18(11 / 5959)$ & $\begin{array}{c}\% 98.4 \\
(5866 / 5959)\end{array}$ & $\begin{array}{c}\text { \%100 yüksek } \\
(11 / 11)\end{array}$ \\
\hline Van, $2015^{19}$ & Gebe & \%2.6 (245/9326) & $\% 100(527 / 527)$ & $\begin{array}{c}\% 100 \text { yüksek } \\
(150 / 150)\end{array}$ \\
\hline \multirow[t]{2}{*}{$\begin{array}{l}\text { Yedi ayrı il, } \\
2015^{20}\end{array}$} & Gebe & $\begin{array}{l}\text { Yedi merkezde } \\
\% 0.2 \text { ila } 3.7\end{array}$ & $\begin{array}{l}\text { Yedi merkezde } \\
\% 87.8 \text { ila } 100^{\star}\end{array}$ & - \\
\hline & & $\begin{array}{l}\text { Tüm olgular } \\
\text { toplamı \%2.56 } \\
(206 / 8059)\end{array}$ & $\begin{array}{l}\text { Tüm olgular } \\
\text { toplamı \%96.8 } \\
(3965 / 4097)\end{array}$ & - \\
\hline \multirow[t]{2}{*}{ Ankara, $2015^{21}$} & Gebe & $\begin{array}{c}\% 0.97(1 / 103) \\
\text { pozitif } \\
\% 0.97(1 / 103) \\
\text { ara değer }\end{array}$ & \%98.1 (101/103) & $\begin{array}{c}\text { \%100 yüksek } \\
(101 / 101)\end{array}$ \\
\hline & Gebe olmayan & $\% 0(0 / 60)$ & $\% 98.3(59 / 60)$ & $\begin{array}{c}\text { \%100 yüksek } \\
(59 / 59)\end{array}$ \\
\hline İzmir, $2017^{22}$ & Gebe & $\begin{array}{c}\% 1.5(14 / 908) \\
\% 1.02(1 / 908) \\
\text { ara değer }\end{array}$ & \%98.9 (898/908) & $\begin{array}{c}\operatorname{lgM} \text { pozitif } 9 \\
\text { olguda: Düşüuk } 0, \\
\text { ara değer 1, } \\
\text { yüksek } 8(\% 88.9)\end{array}$ \\
\hline \multirow[t]{2}{*}{ İstanbul, $2018^{23}$} & $\begin{array}{c}\text { Gebe } \\
\text { (Türk vatandaşı) }\end{array}$ & $\% 0.2(2 / 963)$ & \%99.5 (958/963) & - \\
\hline & $\begin{array}{c}\text { Gebe } \\
\text { (Suriye göçmeni) }\end{array}$ & $\% 0(0 / 103)$ & \%100 (103/103) & - \\
\hline
\end{tabular}

* CMV IgG pozitifliği \%87.8 olan Ordu ili dışındaki diğer altı merkezde \%96-100 aralığında. 
ğının araştırıldığı bir algoritmayı takip eden ve konjenital CMV enfeksiyonlarının gerçek prevalansını belirlemede eksik yönleri olan araştırmalardı ${ }^{15,21}$. İkinci grup çalışmalar ise prevalanstan ziyade ülkemizde görülen konjenital CMV olguları hakkında klinik ve nedensel bilgilerin sunulduğu olgu raporları veya serilerinden ibarettir ${ }^{24-26}$. Ağırlıklı olarak semptomatik enfeksiyonların araştıııldığı ve intrauterin ölüm olgularının dahil edildiği bu çalışmalardan farklı olarak ${ }^{25-27}$, yakın zamanda yapılan az sayıdaki çalışmada konjenital CMV prevalansı doğrudan araştırmaya yönelik algoritmalar kullanılarak izlenmiştir ${ }^{1,28}$ (Şekil 1). Canlı doğan bebeklerde konjenital CMV enfeksiyonu prevalansının araştırıldığı 2015 tarihli bir çalışmada konjenital enfeksiyon sıklığı \%1.9 (18/944) olarak bildirilmiştir $^{1}$. Tükürük örneklerinin gerçek zamanlı polimeraz zincir reaksiyonu (PCR) ile tarandığı ve pozitiflik saptanan olgularda kan ve idrar örneklerinin analiz edildiği bu çalışmada enfekte bebeklerin tamamının doğumda asemptomatik olduğu bildirilmiş, ancak işitme testi sonuçları ile ilgili bir veri sunulmamıştır. Bu çalışmada, enfekte yenidoğanların beşinde sadece tükürük örneklerinde pozitiflik saptanırken, 13 (\%1.4; 13/944)'ünde tükürük örnekleri ile beraber idrar örneklerinde de pozitiflik saptanmıştır ${ }^{1}$. Araştırmacılar, CMV DNA pozitif 18 olguda CMV genotip analizi yapmış ve genotip glikoprotein B-1 (gB1)'in en sık (\%83.3) gözlenen genotip olduğunu bildirmişlerdir. Aynı çalışmada, ikiz iki olguda, hem tükürük hem de idrar örneklerinde iki farklı genotip (gB1 ve gB4) ile çoklu enfeksiyon geliştiği gösterilmiştir ${ }^{1}$. Farklı hasta gruplarında CMV genotip dağılımının araştırıldığı 2016 yılında ülkemizde yapılan bir çalışmada ise konjenital ya da postnatal enfeksiyon ayırımı yapılmaksızın yenidoğanlarda en sık görülen CMV genotipi benzer şekilde gB1 (\%38.4) olarak bulunurken, diğer genotiplerin dağılımı gB3 \%30.8, gB2

\begin{tabular}{|c|c|}
\hline $\begin{array}{l}\text { Yenidoğan tarama çalışması } \\
\text { İstanbul ve Ankara, } 2015\end{array}$ & $\begin{array}{l}\text { Yenidoğan tarama çalışması } \\
\text { İzmir, } 2019\end{array}$ \\
\hline 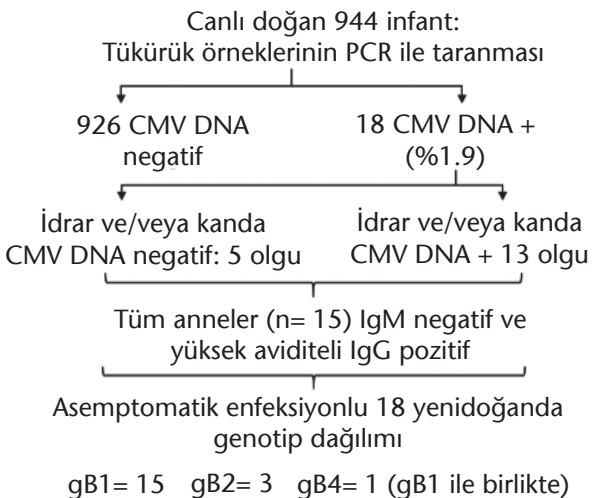 & 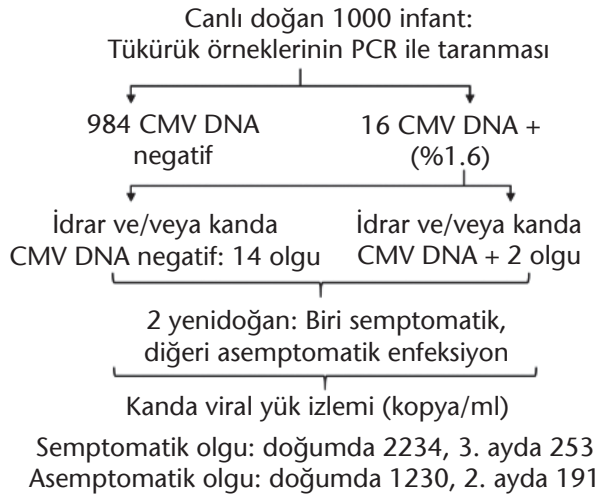 \\
\hline $\begin{array}{l}\text { Konjenital enfeksiyon } \\
\text { oranı \%1.9 (18/944) }\end{array}$ & $\square \begin{array}{c}\text { Konjenital enfeksiyon } \\
\text { oranı \%0.2(2/1000) }\end{array}$ \\
\hline
\end{tabular}

Şekil 1. Türkiye'de yapılan iki yenidoğan konjenital CMV tarama çalışmasında izlenen algoritmalar ve çalışma sonuçları ${ }^{1,28}$.

PCR: Polimeraz zincir reaksiyonu, CMV: Sitomegalovirüs. 
\%15.4 ve gB4 \%7.7 olarak bildirilmiştir ${ }^{7}$ Yenidoğan bebeklerin tükürük örneklerinde CMV DNA varlığının incelenmesi ile konjenital enfeksiyon sıklığının araştırıldığı 2019 tarihli daha yeni bir çalışmada ise tükürük örneklerindeki pozitiflik oranı \%1.6 (16/1000) olarak saptanmıştır ${ }^{28}$. Tükürük örneklerindeki pozitifliğin tek başına konjenital enfeksiyon varlığını kanıtlamak için yetersiz olduğunun belirtildiği bu çalışmada idrar ve kan örneklerinde de viral DNA varlığı araştırılmış ve $2(\% 0.2)$ olguya doğrulanmış konjenital enfeksiyonu tanısı konulmuştur. Bu olguların biri asemptomatik klinik tablo gösterirken, diğerinde sensörinöral işitme kaybı bulunmuştur. Bu çalışmaların her ikisinde de ${ }^{1,28}$ kantitatif analiz gerçekleştirilmiş olup, çalışmaların birinde ${ }^{28}$ ayrıca enfekte bebek izleminde viral yük takibi yapılmıştır. Ancak her iki çalışmadaki olgu sayısı bu konuda bir yorum yapmak için yeterli gözükmemektedir.

\section{Gebelikte Sitomegalovirüs Enfeksiyonları}

Diğer herpes virüslerde olduğu gibi, CMV ile oluşan primer enfeksiyonları da persistan veya latent enfeksiyonlar izler. Araştırmalar, seronegatif anneler için CMV enfeksiyonu kaynağı olarak cinsel aktivitenin ve CMV ile enfekte çocuklarla yakın temasın önemli olduğunu göstermiştir ${ }^{6,14}$. CMV enfeksiyonunun gebelik sırasındaki durumuna göre kadınlar enfekte olmayanlar, latent enfeksiyonu olanlar, primer enfeksiyonu olanlar, latent virüs ile tekrarlayan (reküren-reaktif) enfeksiyonu olanlar ve yeni bir virüs ile enfekte olanlar (reenfeksiyon) şeklinde sınıflandırılabilir ${ }^{21}$. Primer maternal enfeksiyon CMV'nin ilk olarak gebelik sırasında geçirilmesi olarak tanımlanır ve gebelerde mononükleoz benzeri bir hastalık şeklinde geçirilebilir veya asemptomatik olarak seyredebilir ${ }^{6,29}$. CMV'nin intrauterin bulaşında rol oynayan patogenez net bir şekilde tanımlanmamış olmasına rağmen, anne immün yanıtının transplasental CMV geçişinin önemli bir belirleyicisi olduğu gösterilmiştir ${ }^{8}$. Prekonsepsiyonel bağışıklığın intrauterin bulaş ve fetal enfeksiyonun zararlarına karşı sağladığı koruma anne immün yanıtının önemini açıkça göstermektedir. Bu koruma tam olmasa da, primer enfeksiyon ile kıyaslandığında, bağışık annelerde bulaş hızının 10-25 kat daha az olduğu bulunmuştur ${ }^{6,8,29}$. Tüm gebeliklerde dünya genelinde primer maternal CMV enfeksiyonu sıklığının \%1-3 aralığında olduğu tahmin edilmektedir ${ }^{8}$. Primer enfeksiyonlarda virüsün fetüse vertikal geçiş riski ise \%30-40 arasındadır ${ }^{8,14,29}$. Bununla birlikte, bağışık annelerden doğan çocuklarda da konjenital CMV enfeksiyonu gelişebildiği ve bu oranın \%1-2'ye yakın olduğu gösterilmiştir ${ }^{1,12}$. Rubella, parvovirüs ve toksoplazmadan farklı olarak gebelik öncesinde enfeksiyonu geçirmiş ve seropozitif olan annelerden doğan çocuklarda görülebilen primer olmayan maternal CMV enfeksiyonları endojen latent virüsün reaktivasyonuyla veya yeni bir virüs suşuyla reenfeksiyon sonucu oluşabilmekteyken, bağışık kadınlarda CMV'nin transplasental bulaş mekanizmaları açıkça tanımlanmamıştır ${ }^{1,12,26}$. Mevcut veriler immün korumanın yeni bir virüs suşu ile reenfeksiyonu önlemede yetersiz kaldığını göstermektedir ${ }^{8,30}$. Hatta bazı çalışmalarda primer enfeksiyonu olan ve olmayan annelerden doğan bebekler karşılaştırılmış ve semptomatik enfeksiyon varlığı, işitme kaybı ve nörolojik sekel gelişme durumu bakımından iki grup arasında çok az bir fark olduğu gösterilmiştir ${ }^{2,30}$. Seropozitif annelerin doğurganlık ça- 
ğındaki kadın popülasyonundaki artan oranı, konjenital enfeksiyonların oranındaki artışla doğrudan ilişkilidir6,30. Konjenital CMV enfeksiyonu olan tüm bebeklerin \%70-80'inin gebelik sırasında primer olmayan enfeksiyon geçiren kadınlardan doğduğu tahmin edilmektedir ${ }^{30}$. Yüksek maternal seroprevalans ve yüksek konjenital enfeksiyon sıklığı arasında pozitif korelasyon bulunmaktadır. Bu durum primer ve primer olmayan enfeksiyon gelişme riski altındaki popülasyon ve bu enfeksiyonlardaki intrauterin bulaş oranlarıyla doğrudan ilişkili olmakla birlikte, bu oranlar üzerinden yapılan hesaplamalarla prevalansın saptanması mümkün değildir ve toplumların sosyokültürel özellikleriyle ilişkili davranış biçimleri, ekonomik ve demografik özellikleri gibi diğer birçok faktör de konjenital CMV enfeksiyonlarının görülme sıklığını etkilemektedir $8,11,30$.

Amerika Birleşik Devletleri (ABD)'nde konjenital CMV enfeksiyonlarının \%75'inin primer olmayan enfeksiyonlardan sonra görüldüğü tahmin edilmekte olup, bu oran farklı çalışmalarda Finlandiya'da \%54, Brezilya'da \%88.6 olarak bulunmuştur ${ }^{2}$. CMV seroprevalansının yüksekliği Türkiyede primer olmayan CMV enfeksiyonu sonrası gelişen konjenital enfeksiyonların daha sık olduğunu göstermektedir ${ }^{21}$. Ülkemizde yapılan bir çalışmada konjenital CMV enfeksiyonlu bebeğe sahip 15 kadının tümünde yüksek avidite indeksli (75.8-97.6) IgG pozitifliği ve negatif IgM test sonucu raporlanmıştır ${ }^{1}$. Sekiz semptomatik konjenital CMV enfeksiyonu olgusunun sunulduğu başka bir çalışmaya ait veriler ve reküren enfeksiyon sonrası gelişen iki semptomatik konjenital enfeksiyon olgusu da bu veriyi desteklemektedir ${ }^{25,26}$. Literatürde, ülkemizde primer maternal enfeksiyon ilişkili olgu sunumları da mevcuttur. Bu çalışmalardan birinde ${ }^{24}$, primer maternal enfeksiyon sonrası gelişen ve doğumda asemptomatik olan bir olgu sunulmuştur. Bu olguda, gebeliğinin yedinci haftasında seronegatif olan ve 16. haftada IgM pozitifliği ve düşük aviditeli IgG varlığı saptanan bir annede amniyosentezde CMV DNA pozitifliği gösterilmiştir.

\section{Gebelikte İzlem ve Konjenital Enfeksiyon Tanısı}

Konjenital CMV enfeksiyonlarının tanısı ve yönetimi; (a) anne ve anne adaylarının gebelik öncesi dönemde ve gebelik esnasında takibine yönelik uygulamaları, (b) fetal muayene ve tanı testlerini, (c) doğum sonrası yenidoğan muayenesi ve tarama testlerini, (d) uzun dönem nörolojik sekeller için risk altında olan konjenital enfekte bebeklerin takibini ve olası yararlılığı olan tedavi seçeneklerinin değerlendirilmesini kapsayan uzun bir süreçtir.

\section{a. Maternal Enfeksiyon Tanısı ve Gebelik Takibi}

Serolojik testler CMV enfeksiyonlarının değerlendirilmesinde kullanılan ilk basamak testlerdir. ABD ve bazı Avrupa ülkeleri gibi selektif tarama yapılan ülkeler bulunsa da, maliyet-etkinlik ve uygulama güçlüğü gibi gerekçelerden dolayı günümüzde hiçbir ülkede gebelik öncesi ve gebelikte serolojik testlerle rutin CMV taraması yapılmamaktadır ${ }^{2,21}$. Konjenital CMV enfeksiyonlarının önemli bir bölümü primer maternal enfeksiyonlarla ilişkili olsa da, seronegatif annelere yönelik spesifik müdahalelerin olmaması, fetal prognoz hakkındaki belirsizlik ve reaktivasyon-reenfeksiyon ilişkili enfeksiyonların yüksek oranı ru- 
tin maternal antikor taraması konusundaki cesareti kırmaktadır ${ }^{2,4,21}$. ACOG (American College of Obstetricians and Gynecologists), bütün kadınların CMV enfeksiyonunun gebelikte bulaş yolları hakkında eğitilmelerini önermekteyken, gebelikte rutin taramayı onaylamamıştır ${ }^{14}$.

Primer enfeksiyon geçiren annelerin üçte birinden fazlasının intrauterin bulaş ile ilişkili olması, konjenital enfeksiyonların taranmasında öncelikli olarak primer maternal enfeksiyonların belirlenmesi üzerinde durulmasına neden olmuştur. Başka bir spesifik nedene atfedilemeyen grip benzeri semptomları olan veya fetal enfeksiyonu düşündüren görüntüleme bulguları bulunan gebelerde CMV serolojisinin (IgG ve IgM düzeyleri, IgG avidite) değerlendirilmesi önerilmektedir ${ }^{2}$. IgG ve IgM antikor testlerinin her ikisi için de sonuç negatif ise, bireyde CMV enfeksiyonu yoktur ya da henüz serokonversiyon gelişmemiştir $^{6,21}$. IgG pozitif ve IgM negatif ise, bu durum geçirilmiş maternal enfeksiyonu göstermektedir $^{21}$. IgG serokonversiyonunun gösterilmesi primer maternal enfeksiyon için kesin kanıt sağlarken, IgG ve IgM'nin birlikte pozitifliği gebenin büyük olasılıkla yakın zamanda bir CMV enfeksiyonu geçirdiğini göstermektedir ${ }^{2,21}$. Bu durumda avidite testlerinin sonuçlarına bakılmakta ve düşük-orta aviditeli IgG pozitifliği primer enfeksiyon lehine olmaktadır². Bu testlerin sonuçlarının gebeliğin 12 ila 16. haftalarından önce birlikte değerlendirilmesi yaklaşımı semptomatik konjenital enfeksiyon gelişme riskini öngörmede sık başvurulan bir uygulamadır².

Tanı laboratuvarları tarafından kullanılan ticari CMV IgM testlerinin çoğu enzim immunoassay formatını kullanmakta ve bağışık erişkinlerde tahmin edilen duyarlılıkları \%50-90 arasında değişmektedir. Bu testler yanlış pozitif sonuçlarından dolayı günümüzde doğum öncesi serolojik taramada rutin olarak kullanılmamaktadır. IgG ve IgM antikor seviyelerinin önemi hakkındaki hatalı varsayımlar fetal risk öngörüsü ile ilgili yanlış bilgi de sunabilmektedir. CMV'ye karşı oluşan IgM antikorların primer enfeksiyon göstergesi olarak değeri, IgM antikorlarının primer enfeksiyondan sonra uzun süren varlıkları, reaktivasyon veya farklı bir CMV suşu ile reenfeksiyon durumlarında saptanabilmesi ve ticari CMV IgM antikor testlerinin duyarlıık eksikliği nedenleriyle sınırıdır ${ }^{6,14}$. Bu nedenle, klinisyenlerin primer maternal CMV enfeksiyonunun serolojik tanı sınırlarını anlaması esastır.

Primer enfeksiyon tanısında IgG serokonversiyonunu doğrulamak için çoğu durumda ardışık serum örnekleri mevcut olmadığı için bu durumu kanıtlamak mümkün değildir. Bu nedenle primer ve nonprimer maternal enfeksiyonlar arasında ayrım yapabilmek için IgG avidite indeksinin belirlenmesine başvurulur ${ }^{31}$. Yapılan çalışmalarda genel olarak primer enfeksiyonu olan hastaların > \%85'inin düşük avidite, geçirilmiş enfeksiyonu veya reaktivasyonu olan hastaların > \%90'ının ise yüksek avidite sergilediği gösterilmiştir ${ }^{31}$. Bir çalışmada, gebelik haftası 14 veya daha düşük olan kadınların serum örneklerinde lgM pozitifliği ve düşük IgG avidite indeksi birlikteliğinin \%83.3 duyarlılı, \%83.8 özgüllük ve \%99.1 negatif prediktif değer ile konjenital enfeksiyonun güçlü bir göstergesi olduğu bildirilmiştir². IgG avidite testi CMV bulaşından sonraki ilk 3-4 aylık sürede antiviral IgG antikorlarının afinite olgunlaşmasının tam olmadığının gözlemlenmesine, yani pri- 
mer enfeksiyonu takiben ilk birkaç hafta ile birkaç ay boyunca üretilen lgG antikorlarının genellikle düşük aviditeli olması esasına dayanmaktadır ${ }^{31}$. Avidite testlerinin sınırlamaları arasında 18. haftadan sonra daha az bilgilendirici sonuç elde edilmesi, eşik değerlerinin farklı ticari testler arasında değişiklik göstermesi ve nadir durumlarda lgM pozitifliği ile birlikte olabilen düşük avidite persistansının (> 18 hafta) yanlış tanıya neden olabilmesi durumları yer alır ${ }^{29}$. Farklı viral epitoplara karşı antikor üretiminin değişken süreleri nedeniyle uzun süren vireminin avidite olgunlaşma süresini etkileyebileceği de öne sürülmüştür ${ }^{32}$. Illk trimestırdaki yüksek IgG avidite sonucu primer enfeksiyonu dışlarken, ikinci veya üçüncü trimestırdaki orta-avidite veya yüksek-aviditeli bir sonuç gebelikteki primer enfeksiyonu dışlamak için yetersizdir ${ }^{31}$. CMV IgG avidite testleri gebelik sürecinde primer enfeksiyon tanısı için etkinliği kanıtlanmış değerli bir araçtır, bununla beraber IgG avidite testlerinin primer enfeksiyon varlığını açık bir şekilde tanımlayamadığı durumların olduğu da bilinmelidir 6,31 .

Primer enfeksiyonlu annelerden doğan bebeklerin yalnızca \%30-40'ının enfekte olarak doğması ve konjenital enfeksiyonlu bebeklerin sadece \%8-18'inin doğumda semptomatik olması dolayısıyla primer enfeksiyon varlığını ortaya koymanın tek başına konjenital enfeksiyon riskini değerlendirmede yetersiz kalacağı öngörülerek kültüre dayalı, serolojik veya moleküler yöntemlerle kan veya servikovajinal sekresyonlar gibi periferal vücut sıvılarında viral replikasyonun gösterilmesi üzerinde durulmuş ve bu yaklaşımın potansiyel bir belirteç olabileceği öne sürülmüştür ${ }^{8,9,14,29}$. CMV enfeksiyonlarında virüs atılımı genelde asemptomatiktir ve bireyler genellikle enfekte olduklarının ve virüs saçtıklarının farkında değillerdir. Serviks ve vajinadan CMV atıımı oranları gebelik sırasında değişebilmektedir, gebeliğin erken dönemlerinde düşük olan bu durum, geç gebelikte gebe olmayan kadınlara eşit veya daha fazla olacak şekilde artış gösterir ${ }^{6}$. Kontrol grubu ile gebelerin karşılaştırıldığı iki ayrı çalışmanın birinde gebe olmayan kadınlarda CMV atılımının ilk ve ikinci trimestırlarda kontrol grubuna göre daha düşük olduğu, üçüncü trimestırda aynı düzeye geldiği ${ }^{33}$, diğer çalışmada ise tüm trimestırlarda gebelikte CMV atılımının kontrol grubuna göre daha yüksek olduğu bulunmuştur ${ }^{34}$. Doğum sırasında servikal sekresyonlarından CMV atılımı olan kadınların oranı ABD'de yaklaşık olarak \%10 iken, bu oran Tayvanlı kadınlarda \%40 gibi daha yüksek oranlarda bulunmuştur ${ }^{33,34}$. Ülkemizde yapılan bir çalışmada ise, planlı sezaryen operasyonu öncesi gebelerden alınan idrar ve/veya kan örneklerinde CMV DNA pozitiflik oranı \%5.8 (5/103) olarak bulunurken, bu oran gebe olmayan kontrol grubu kadınlarda \%1.9 (2/60) olarak bulunmuştur ${ }^{21}$. Gebelik sırasında ve sonrasında CMV atılımı göreceli olarak yaygın bir durum olmasına rağmen, yapılan çalışmalar gebelik sırasında idrar veya serviksten veya her iki bölgeden virüs izolasyonunun ya da moleküler yöntemler ile CMV DNA varlığını saptamanın intrauterin bulaş için prediktif olmadığını ve semptomatik enfeksiyon gelişimi ile korelasyonunun düşük olduğunu göstermiştir ${ }^{6,34}$. Intrapartum CMV bulaşının ise doğum sırasında serviks veya vajinal kanaldan CMV saçan annelerden doğan bebeklerin yaklaşık \%50'sinde oluştuğu bildirilmiştir6. 


\section{b. Amniyon Sıvısı ve Plasental-Fetal İncelemeler}

Ultrasonografi (USG), amniyosentez ve fetal kan örneklemesi (kordosentez) ile prenatal dönemde konjenital CMV enfeksiyonu tanısı konulabilmektedir ${ }^{29}$. Prenatal USG, semptomatik fetal enfeksiyona işaret eden yapısal veya büyüme anormalliklerinin tanımlanmasına yardımcı olur. Bu anormal bulgular ekojenik bağırsak, intrauterin gelişme geriliği, plasental kalınlaşma, ventrikülomegali, intrakraniyal kalsifikasyonlar, mikrosefali, hidrops fetalis ve/veya anormal amniyon sıvısı hacmini içerir. Bununla birlikte, konjenital CMV enfeksiyonu varlığının değerlendirilmesinde USG duyarlı değildir ve bulgular konjenital $C M V^{\prime} y e$ özgü değildir ${ }^{14}$. Gebeliğin erken döneminde primer CMV enfeksiyonu olan kadınların dahil edildiği bir çalışmada doğrulanmış konjenital enfeksiyonlu fetüslerin sadece \%37.7'sinin ultrasonografik anormallikler gösterdiği ve otopsi sonuçları, postnatal klinik bulguları veya fetal USG değerlendirmesi normal olan bebeklerin \%55'inde ise CMV ilişkili anomalilerin varlığı tespit edilmiştir ${ }^{35}$. Bu kısıtlılıklarına rağmen, doğrulanmış primer maternal CMV enfeksiyonu olan bir gebede ultrasonografik anomalilerin varlığı, fetal enfeksiyon olasılığının yüksek olduğuna işaret etmektedir.

Konjenital enfeksiyon varlığını doğrulamanın en iyi yolu gebeliğin 20-21. haftalarından sonra amniyotik sıvıda CMV DNA varlığının gösterilmesi veya alternatif olarak virüs izolasyonudur ${ }^{2}$. Viral kültür ve $P C R$ testlerinin ikisi de negatif ise konjenital CMV enfeksiyonu güçlü bir şekilde dışlanabilirken, bu testlerin pozitifliği ile fetal enfeksiyon varlığı gösterilir ancak enfeksiyonun fetüs üzerindeki etkisi tespit edilemez. Fetal beyin tutulumu belirtileri veya amniyotik sıvıda kantitatif PCR ile viral yük analizinin ek prognostik bilgi sağlayabileceği bildirilmiştir ${ }^{14}$. CMV'nin yavaş çoğalan bir virüs olması ve erken gebelikte fetal böbrekler tarafından yeterli miktarlarda atılmaması nedeniyle 21-22. gebelik haftalarından önce yapılan amniyosentezde CMV DNA saptanamayabilmekte ve yanlış negatif sonuçlar elde edilebilmektedir. Bu durum, testin duyarlılığının 20. hafta öncesinde sadece \%45 olmasına yol açmaktadır ${ }^{2,14}$. Membran rüptürü gibi riskleri nedeniyle bu invaziv yaklaşımın tüm gebelere uygulanması gerçekçi bir yaklaşım olmadığı gibi, asemptomatik fetüslerde kullanılması ise halen tartışmalıdır ${ }^{14,36}$. Bununla birlikte, fetal tıp uzmanı biri tarafından yapıldığında çok küçük bir risk taşıyan bu işlemin primer CMV enfeksiyonu olan veya USG ve serebral manyetik rezonans görüntüleme (MRG) incelemelerinde anormal bulguları olan gebelerde olgu yönetiminde kullanılabileceği belirtilmektedir ${ }^{2,14,37}$. Ek olarak, amniyotik sıvının antenatal testlerinde konjenital CMV enfeksiyonu için yanlış pozitif ve yanlış negatif sonuçlar bildirilmesi nedeniyle bu test sonuçlarının doğum sonrası doğrulanması önerilmektedir ${ }^{37}$. Sonuç olarak; doğum öncesi USG, fetal MRG, fetal kanda trombosit sayımı ve IgM seviyelerinin ölçülmesi, amniyotik sıvı veya fetal kanda CMV DNA saptanması yaklaşımlarıyla klinik sonuçlar kesin bir şekilde öngörülememekle birlikte ${ }^{2,29}$, fetal ve maternal örneklerindeki viral yük ile enfekte yenidoğanların klinik sonuçları arasında güçlü bir ilişki olduğunu bildiren çalışmalar da bulunmaktadır 29,38 . 


\section{c. Yenidoğanlarda Klinik ve Laboratuvar Tanı}

Konjenital CMV enfeksiyonlu bebeklerin \%5-10'unu oluşturan semptomatik yenidoğanların tanısında konjenital enfeksiyon varığını destekleyen belirli klinik ve laboratuvar bulgular saptanmaktadır. Hepatosplenomegali, peteşi-purpura ve sarılık en sık görülen bozukluklardır ve semptomatik yenidoğanların yaklaşık \%75'inde bulunur ${ }^{6,37}$. Diğer sık görülen semptomlar düşük doğum ağırlığı, mikrosefali, hipotoni, zayıf emme, letarji ya da nöbetler gibi klinik nörolojik anomaliler iken, koriyoretinit, optik atrofi, retinal hemoraji, hidrosefali, anormal işitme testi varlığı (tek veya iki taraflı) ve pnömoni de saptanabilmektedir $2,6,28,37$. Semptomatik konjenital CMV enfeksiyonu olan bebeklerde görülen anormal laboratuvar sonuçları arasında serum aspartat aminotransferaz (AST) yüksekliği, konjuge hiperbilirubinemi, trombositopeni, atipik lenfositoz, lökopeni, izole nötropeni, hemolitik anemi ve artmış beyin omurilik sıvısı (BOS) proteini değerleri yer almaktadır 6,37 . BOS anormallikleri, özellikle de yüksek protein varlığı (> 120 mg/dl) SSS hasarının klinik göstergeleri ile ilişkilidir ${ }^{6,37}$. Semptomatik konjenital CMV enfeksiyonu olan bebeklerin yaklaşık \%70'i anormal MRG bulgularına sahiptir, intraserebral kalsifikasyon en sık bulgudur. Daha az sıklıkla görülen bulgular ise ventriküler dilatasyon-kist, kortikal atrofi, serebellar hipoplazi, beyaz cevher ve göç anormallikleridir ${ }^{2,6,27,37}$. Enfekte yenidoğanlarda antiviral tedavi kararının verilmesinde bir ölçüt olarak kullanılmak üzere semptomatik konjenital CMV hastalığı "şiddetli", "orta" ve "hafif" şeklinde üç kategoriye ayrılmıştır². Bu tanımlamalar Avrupa Çocuk Enfeksiyon Hastalıkları Derneği (ESPID)'nin 2015 yılında Leipzig'de düzenlenen toplantı raporlarının derlendiği bir makalede detaylandırılmıştır ${ }^{37}$.

Enfekte bebeklerin \%85-90 gibi daha büyük bir grubunu oluşturan asemptomatik yenidoğanların tanısı farklı laboratuvar testlerini gerektirmektedir. Konjenital CMV enfeksiyonu tanısı yaşamın ilk iki haftası boyunca vücut sıvılarında virüs izolasyonu veya viral DNA varlığının gösterilmesiyle kanıtlanır ${ }^{1}$. Doğum sırasında veya anne sütü ile CMV bulaşan yenidoğanlar üç hafta sonra virüs atılımına başlarlar. Bu nedenle, üçüncü haftadan sonra idrar veya tükürükte CMV varlığı intrauterin CMV bulaşının kesin bir kanıtı değildir6 ${ }^{6}$ Konjenital CMV enfeksiyonlarının tanısında idrar ve tükürük örneklerinin viral kültürü altın standart yöntem iken, günümüzde duyarlılık ve özgüllükleri yüksek gerçek zamanlı PCR testleri ile CMV DNA saptanması yenidoğan taramalarının temelini oluşturmaktadır2,37. CMV enfeksiyonları için büyük ölçekli tarama hedeflendiğinde PCR testi daha uygun bir yaklaşımdır, çünkü bu yöntem hızlı sonuç vermekte, saklama ve nakil koşullarından etkilenmemekte ve kültürden daha düşük maliyetli olması nedeniyle yüksek verimlilikte sonuçlar sunmaktadır ${ }^{1,28}$. Tükürük örneklerinin (ağız sürüntüsü) kolay toplanıyor olması bu yöntemi daha kullanılabilir kılmaktadır. Bir çalışmada sütünde CMV olan annelerin bebeklerinde emzirme sonrası 30 dakika içerisinde alınan tükürük örneğinin test sonuçlarını yanlış pozitif olarak etkileyebileceği gösterilmiştir ${ }^{39}$. Bu olasılığın oranı her ne kadar çok düşük de olsa, kontaminasyon olasılığı şüphesini ortadan kaldırmak için tükürük örneklerinin emzirme sonrası en az bir saat beklenerek alınması önerilmektedir ${ }^{2,39}$. 
Yenidoğanların tükürük ve idrarlarında yüksek miktarlarda virüs bulunmakta, bu durum CMV tespitini kolaylaştırmaktadır ${ }^{1,6,37}$. PCR ile viral DNA tespiti konjenital CMV tanısında idrar örneklerinde \%100 duyarlılık ve \%99 özgüllüğe sahipken, tükürük örneklerinde \%97'nin üzerinde duyarlılık ve \%99 özgüllüğe sahiptir ${ }^{2,37}$. CMV primer enfeksiyonun ardından periferik kan mononükleer hücreleri ve kemik iliğinde latent olarak kalır, ancak periferik kandaki viral nükleik asit miktarı enfekte yenidoğanların tümünde saptanabilir düzeylerde değildir ${ }^{1,6}$. Ülkemizde yapılan bir çalışmada hem idrar hem de tükürük örneklerinde CMV DNA pozitifliği bulunan konjenital CMV enfeksiyonlu iki yenidoğanın eş zamanlı kan örnekleri de CMV DNA pozitif olarak bulunurken, bir diğer çalışmada idrar ve tükürük örnekleri pozitif olan yenidoğanların sadece üçte birinin (\%30.8, 4/13) eş zamanlı kan örneklerinde CMV DNA pozitifliği saptanmıştır ${ }^{1,28}$. Paradoksal olarak ağır CMV hastalığı olan bebeklerde bile kanda saptanabilir düzeyde CMV bulunmama olasılığı bildirilmiştir ${ }^{29,37}$. Enfeksiyonun farklı dönemlerindeki kompartımentalizasyon nedeniyle yaşamın ilk iki haftalık döneminde alınan kan örneklerinde DNAemi (tam kan, plazma, serum veya lökositlerde viral DNA gösterilmesi) gözlenmeyebilir, bu nedenle kan örneklerinde PCR ile CMV DNA analizi konjenital CMV enfeksiyonunu dışlamak için kullanılmamalıdır 29,37 . Doğru test seçimi enfekte bebeklerin saptanması ve tedavisinde önemli olduğu gibi, hastalık prevalansının ve toplum üzerindeki olumsuz etkisinin büyüklüğünün ortaya konması bakımından da önemlidir. Britanya Kolombiya'sında yapılan bir araştırma, klinisyenlerin yenidoğan CMV hastalığı tanısı için eğitim almış olmalarının önemini ortaya koymuştur. Bu çalışma klinisyenlerin CMV test istemlerinin enfekte yenidoğanların \%10'undan daha azında erken tanı koyabildiğini göstermiştir ${ }^{40}$. Yenidoğanlarda rutin tarama için kart (Guthrie kartı) üzerine alınan kan örneklerinin (dried blood spot, DBS) PCR ile incelenmesi retrospektif bir yaklaşım olarak değerlendirilebilir, ancak duyarlılığı \%84 civarındadır ve test edilen popülasyona ve kullanılan laboratuvar tekniklerine bağlı olarak değişkendir, bu nedenle negatif bir DBS PCR testi konjenital CMV tanısını dışlamak için kesin bir kanıt sağlamaz ${ }^{37}$. Konjenital CMV tanısı için bebeklerin kanında IgM antikor tespiti ise viral izolasyon kadar güvenilir değildir ve konjenital enfeksiyon tanısı için tavsiye edilmemektedir ${ }^{6}$. BOS'da prognoz belirteci olarak beta-2 mikroglobulin ve CMV DNA varlığı araştııılmış olsa da, mevcut kanıtlar rutin tanının bir parçası olarak BOS incelemesini desteklememektedir ${ }^{37}$.

Bazı çalışmalar enfekte yenidoğanların idrar ve tükürük salgılarındaki viral yük düzeyi ile semptomatik enfeksiyon varlığı ve uzun dönem sekel gelişme riski arasında ilişki olduğunu ortaya koymuştur ${ }^{5,6,28}$. CMV DNA pozitifliği dışında herhangi bir bulgusu olmayan yenidoğanların değerlendirilmesinde kanda viral yük analizinin yararlı olabileceği bildirilmiştir ${ }^{37}$. Asemptomatik yenidoğanlarda doğumda ve yaşamın ilk ayında düşük CMV DNA kan viral yükünün normal gelişim göstergesi olarak prediktif değer taşıdığı bildirilmiştir ${ }^{4}$. Primer enfeksiyonlu kadınlardan doğan asemptomatik konjenital enfeksiyonlu yenidoğanlarda yüksek CMV DNAemi düzeylerinin CMV ilişkili sekellerle ilişkili olduğu ve prediktif değer taşıdığını gösteren bir çalışmada, işitme kaybı riskinin viral yük artışı ile ilişkili olduğu da gösterilmiştir ${ }^{41}$. 


\section{d. Konjenital Enfeksiyonlu Bebeklerin İzlenmesi}

Gebelikte doğrulanmış CMV enfeksiyonu varlığında, ebeveynlere uygun danışmanlık ve rehberlik sağlamak için fetal enfeksiyon riskini değerlendirmek önemlidir. Prenatal takipte yaygın olarak kullanılan USG bulgularının konjenital CMV enfeksiyonu için özgül olmadığı dikkate alınmalı ve konjenital CMV'nin ayırıcı tanısı yapılmalıdır. Gecikmiş işitme kaybının erken tanısı için yenidoğanların işitme testleri ile taranması veya antiviral tedavi planlanması gibi bir dizi diğer umut verici girişim de denenmektedir. Iş̧itme kaybının erken tanısı konjenital enfekte çocukların konuşma terapisi veya işitme cihazlarıyla desteklenerek dil, duygusal, bilişsel, sosyal gelişimlerindeki olası gerilemelerinin önüne geçilmesine imkan vermektedir ${ }^{4,42}$. Dünya genelinde 1000 canlı doğumda 1-3 olan doğumsal işitme kaybı sıklığının ülkemizdeki oranı 2.2 olup, bu oranın yoğun bakım ünitesinde tedavi görenler gibi riskli gruplarda \%1-6'lara çıktığı tahmin edilmektedir ${ }^{42,43}$. Türkiye'de her yenidoğan için rutin bir uygulama olarak işitme testiyle tarama yapılmaktadır. İşitme kaybı saptanan yenidoğanların konjenital CMV enfeksiyonu için taranması (hedefli tarama) ve tedavi gereksinimi yönünden değerlendirilmesi gerekmektedir ${ }^{44}$. Bununla birlikte, CMV ilişkili işitme kaybı olan bebeklerin çoğunluğunun doğumda normal işitme duyusuna sahip olması ve bu bebeklerde ilerleyen dönemde geç başlangıçı (olguların \%50'sinden fazlasında ilerleyici olan) işitme kaybı gelişmesi nedeniyle ilk tarama sonuçlarının işitme kaybı sıklığını gerçekte olduğundan düşük gösterebileceği unutulmamalıdır ${ }^{4,44}$.

\section{Koruyucu Önlemler ve Tedavi}

Konjenital CMV enfeksiyonlarını önlemede, primer enfeksiyon gelişimini engellemek için gebe kadınların el hijyeni eğitimi de dahil olmak üzere konjenital CMV enfeksiyonları ve koruyucu önlemler hakkında bilgilendirilmesi, hiperimmünglobulin (HIG) veya antiviral tedavi gereksinimi olanları belirlemek için doğum öncesi maternal taramaların yapılması en sık başvurulan önlemler arasında yer almaktadır (Şekil 2) ${ }^{2,11}$. Bir çalışmada sağlık hizmeti veren personelin gebe annelere bilgi aktarma konusundaki eksiklikleri üzerinde durulmuş ve bu yetersizliği gidermek için sağlık hizmeti personelinin (özellikle çocuk doktorları, doğum uzmanları ve ebelerin) hastalarına danışmanlık yapabilmeleri amacıyla konjenital CMV enfeksiyonunun riskleri, önleyici uygulamalar ve tedavisi hakkında eğitim almalarının önemi vurgulanmıştır ${ }^{2}$. Standart önlemlerin dışında, kan ürünleri ile CMV bulaşının önlenmesi için seronegatif donörlerin seçilmesi veya lökositler için özel filtrelerin kullanılması ve in vitro fertilizasyon uygulamalarında bulaşı önleyebilmek için serolojik tarama yapılması gibi farklı yaklaşımlar da önerilmiştir ${ }^{21,45}$.

\section{a. Standart Koruyucu Önlemler}

Kişiden kişiye CMV bulaşı enfekte vücut sıvılarıyla teması gerektirir, bu nedenle standart enfeksiyon kontrol önlemleri CMV enfeksiyonlarının önlenmesinde kritik öneme sahiptir $^{2,6}$. CMV aşılarının enfeksiyonu önlemedeki sınırlı başarısı göz önüne alındığında, gebelerin tükürük ve idrarlarıyla virüs saçan küçük yaştaki çocuklarla temas durumundaki davranışlarına yönelik eğitimler enfeksiyon bulaşını önlemenin etkili bir yolu olarak gö- 


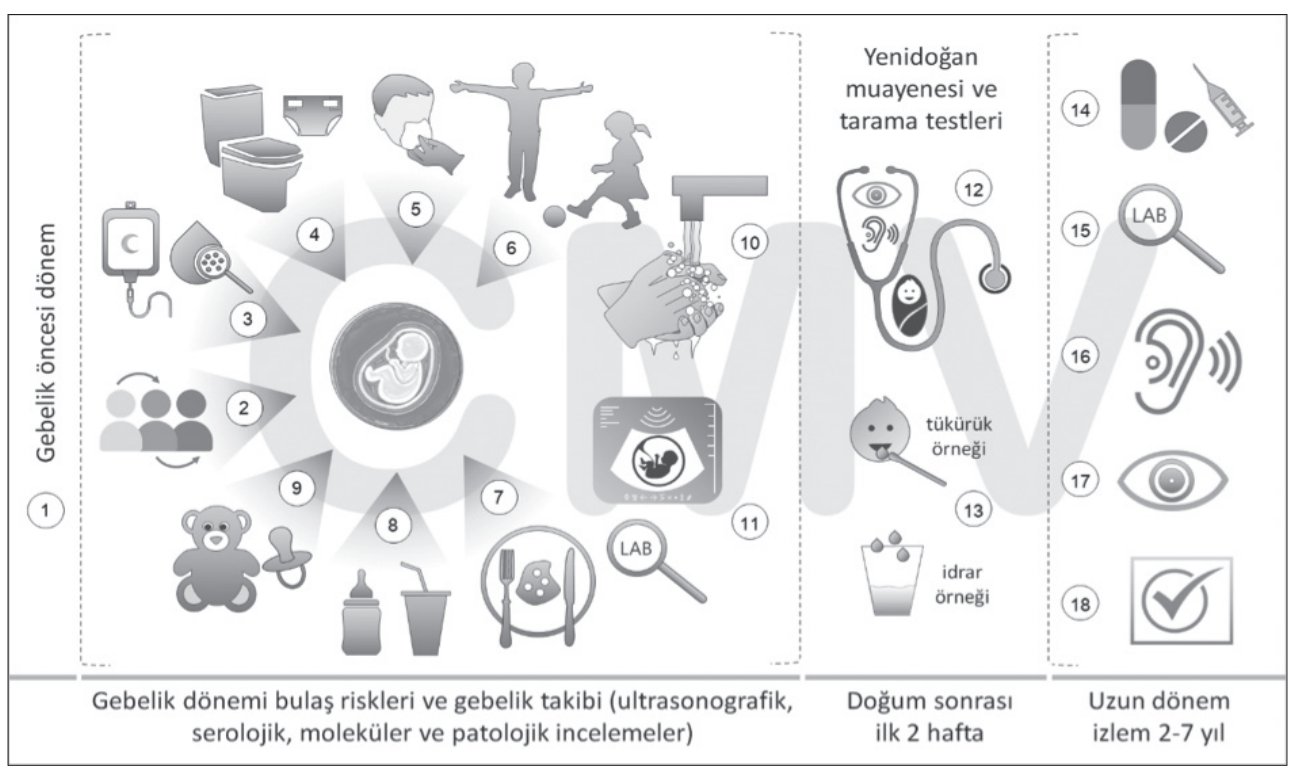

Şekil 2. KCMV enfeksiyonları ve ilişkili sekellerin önlenmesinde koruyucu uygulamalar ve olgu yönetiminde temel basamaklar (2,21,37,44-46). 1: Prekonsepsiyonel dönemde yapılan CMV IgG testi gebelikte primer CMV enfeksiyonu tanısı için yardımc olabilir, bununla beraber tüm gebelere rutin uygulama önerilmemektedir. 2: $C M V$, enfekte kişilerin tükürük ve idrar gibi vücut salgıları ile bulaştığı için standart enfeksiyon kontrol önlemlerine uyulmalı, gebelik döneminde riskli davranışlardan kaçınılmalıdır. 3: Kan ve kan ürünleri için seronegatif donörlerin seçilmesi, özel lökosit filtrelerinin kullanılması veya in vitro fertilizasyon uygulamalarında serolojik tarama yapılması gibi ek önlemler alınabilir. 4,5,10: Çocuk bezi değiştirdikten, bir çocuğu besledikten veya küçük bir çocuğun tükürük veya burnunu sildikten sonra ve kontamine olması muhtemel eşyalara dokunulduğunda eller yaklaşık 15 ila 20 saniye boyunca iyice yıkanmalıdır. 6: Çocukların tükürük salgıları ile temastan kaçınılmalıdır (yüzü yerine başından öpmek veya sarılmak gibi). 7,8: Küçük çocuklar tarafından kullanılan kaşık, bardak, tabak, diş firçası gibi gereçler ve yiyecek-içecekler paylaşılmamalıdır. 9: Oyuncaklar ve mutfak tezgahı temiz tutulmalı, çocuk emzikleri ağıza sokulmamalıdır. 11: CMV enfeksiyonunu düşündüren semptomları veya fetal enfeksiyonunu düşündüren görüntüleme bulguları olan gebelerde serolojik durum değerlendirilmelidir, endikasyon varlığında amniyotik sıvıda viral DNA varlığı araştırılabilir. 12: Yenidoğanların işitme taraması dahil rutin muayenesi ve şüpheli semptomlar yönünden değerlendirilmesi ve ayıııc tanı (örn. diğer konjenital enfeksiyonlar) yapılması önemlidir. 13: Enfeksiyonun uzun dönem olumsuz etkilerinin azaltılmasında (müdahale-tedavi) kritik önem taşıyan enfekte yenidoğanların erken tanısı için idrar ve tükürük (kuru svap veya viral transport vasatı içinde) veya her iki örnekte CMV DNA varlığı araştırıır. 14: Orta dereceli ve ciddi semptomatik hastalığa sahip doğumsal enfekte yenidoğanlara valgansiklovir tedavisi önerilir, tedaviye yaşamın ilk ayında başlanılmalı ve süresi altı ayı geçmemelidir. 15: Transaminaz seviyeleri aylık olarak izlenmeli ve tedavi süresince uygun aralıklarla nötrofil sayımı yapılmalıdır. Viral yük takibi yapılabilir, ancak bu konuda net bir görüş birliği bulunmamaktadır. 16: Odyolojik testler ilk yıl 3-6 ayda bir, 3 yıla kadar 6 aylık aralıklarla ve 6-7 yaşına kadar yılda bir kez yapılmalıdır. 17: Illk erken değerlendirme sonrası oftalmolojik muayene takibi göz doktorunun önerisine göre beş yaşına kadar yapılır. 18: Bir yaşında başlamak üzere gelişim ve nörogelişimsel durumun değerlendirilmesi önerilmektedir.

rülmüştür ${ }^{2}$. Gündüz bakım merkezlerinde, küçük çocukların yaklaşık \%80'inin iki yıl içerisinde CMV enfeksiyonu geçireceği tahmin edilmektedir ${ }^{14}$. Doğuştan enfekte olmayan çocuklarda, virüs atılımı genellikle 1-2 yaşta zirveye ulaşıp, ardından beş yaşına kadar düşüş eğilimi gösterirken, bu çocuklar yakın temasta bulundukları diğer çocuklara CMV bulaşında ve virüsün toplumsal yayılımında önemli bir rezervuar niteliğinde kabul edil- 
mektedirler 5 ,6 İki yaşın altında gündüz bakımevlerine devam eden çocuğu olan annelerin yaklaşık \%30'unda bir yıl içinde serokonversiyon görülmekte, birden fazla çocuğu olan kadınlar ise daha yüksek bir risk taşımaktadırlar ${ }^{2,14}$. Doğum sırasında veya anne sütünden CMV bulaşan bebeklerde ise, yaşamlarının ilk beş yılında düzenli olarak azalmak kaydıyla yıllar boyunca virüs atılımı olmakta ve yakın temasta oldukları diğer çocuklar ve bakıcıları için virüs kaynağı olarak rol almaktadırlar ${ }^{5,6}$. CMV seronegatif kadınların, günlük bakımevindeki çocuklara maruz kalmaları durumunda 5-25 kat artan CMV gelişme riski taşıdıkları gösterilmiş ve önleme girişimleri temel olarak küçük çocukların annelerine odaklanmış$\operatorname{tır}^{14}$. Bu çocuklardan bulaşan vücut sıvılarıyla teması azaltmaya yönelik hijyenik ve davranışsal değişikliklerin gebe kadınlarda serokonversiyon oranını azaltı̆̆ı gösterilmiştir². Ancak bu uygulamaların güvenliği, etkinliği ya da maliyet-etkililiklerine dair belirsizlikler ve ayrıca konjenital CMV hastalığı yükünün büyüklüğü konusunda farkındalık eksikliği nedeniyle bu halk sağlığı müdahaleleri nadiren uygulanmaktadır ${ }^{11}$.

Bebeklik döneminde anneden çocuğa CMV bulaşının bir diğer temel yolu ise anne sütüdür. Seropozitif kadınların \%27-70'inin anne sütü ile CMV bulaştırdığı ve CMV bulaşının anne seroprevalans oranları ve emzirme süresi ile doğrudan ilişkili olduğu bildirilmiştir $^{6}$. Her ne kadar gebelik sırasında endişe etmek gerekli olmasa da, transplante organlar, kan ve kan ürünleri de CMV bulaşında rolü olduğu bildirilen diğer kaynaklardır6,7. Paketlenmiş kırmızı kan hücresi, lökosit ve trombosit transfüzyonu ile CMV bulaşı seronegatif küçük prematüre bebekler ve immün sistemi baskılanmış hastalar için ciddi hastalık riski oluşturmaktadır ${ }^{6}$. Hücresel immün yanıt eksikliği olan kadınlarda (kazanılmış immün yetmezlik sendromu gelişen veya immünsupresif tedavi alan) CMV enfeksiyonu gelişme riski daha yüksektir ve nötralizan antikor üretme olasılığı daha düşük olduğundan virüsün fetüse bulaşma riski de daha yüksektir ${ }^{11}$. Hastane kaynaklı CMV enfeksiyonu için bir diğer potansiyel kaynak üreme tıbbı alanında özel bir yeri olan in vitro fertilizasyon uygulamaları için bağışlanan semendir. İn vitro fertilizasyona atfedilen konjenital CMV enfeksiyonu olgusu bildirilmemiş olsa da, cinsel aktivitenin CMV enfeksiyonu için bir risk olması ve bu virüsün spermden yaygın olarak elde edilebilir olması önemlidir6́.

\section{b. CMV Aşıları ve Etkinlikleri}

Gebelik sırasında primer CMV enfeksiyonu olan kadınlarda transplasental bulaşın nonprimer maternal CMV enfeksiyonu sonrasında meydana gelen bulaştan 10-25 kat daha fazla ortaya çıktığı bulgusu, semptomatik konjenital CMV enfeksiyonunun neredeyse sadece primer anne CMV enfeksiyonunu takiben meydana geldiğinin düşünülmesi ve semptomatik konjenital CMV enfeksiyonu olan çocukların çoğunluğunda nörolojik sekel geliştiğini gösteren bulgular gebelik sırasında primer CMV enfeksiyonunu önlemeye yönelik aşı geliştirme stratejilerine öncülük etmiştir ${ }^{6}$. Yeni geliştirilecek aşılar arasında CMV aşısının yüksek öncelikli olduğuna dikkat çekilmiştir ${ }^{14}$. CMV aşısı geliştirmenin önünde biyolojik bir engel olmadığını gösteren dört tip kanıt bulunmaktadır ${ }^{47}$. Birincisi hayvan çalışmalarına ait sonuçlardır. İkincisi konjenital CMV enfeksiyonunun insanlardaki doğal seyridir; bağışıklığı olan annelerde intrauterin CMV bulaşının daha düşük oranlarda oluşu 
ve nörolojik yıkımın daha hafif oluşu seropozitifliğin koruyucu etkisini göstermektedir. Üçüncü tip kanıt doğal enfeksiyonun indüklediği bağışıklı̆ın immün kompetan erişkinlerde reenfeksiyon oranlarını düşürmesidir. Dördüncü kanıt ise intravenöz (IV) immünglobulin uygulamalarından elde edilen olumlu sonuçlardır. CMV aşı stratejilerinde, gB, pp65 ve IE1 proteinleri potansiyel hedefler olarak değerlendirilmiş ve bu proteinler zayıflatılmış CMV Towne izolatı, tam uzunluktaki antijenleri ve epitopları kodlayan rekombinant viral vektörler, DNA aşıları, dens body ve subunit aşılar da dahil olmak üzere çok sayıda farklı platform ile birlikte denenmiştir ${ }^{8,46,48}$. Son zamanlarda, tipik olarak serum antikor yanıtını indükleyen bir antijen olan CMV zarf proteini gB'yi hedef alan bir aşı, faz 2 klinik deney aşamasına ulaşmışıı ${ }^{14}$. Adölesan kızlarla yapılan bir çalışmada CMV gB aşısının iki dozdan sonra serokonversiyon için $\% 45$ seviyesinde etkin olduğu bildirilmiştir ${ }^{49}$. CMV için aşı geliştirilmesine yönelik yoğun çalışmalar devam etmesine rağmen henüz lisans almış bir aşı mevcut değildir. Diğer taraftan nonprimer enfeksiyonlarla ilişkili konjenital CMV sıkıı̆ı aşı çalışmalarının konjenital enfeksiyonları önlemede beklenen yararlılı̆ı sağlayamayacağına işaret etmektedir ${ }^{30}$.

\section{c. Tedavi Seçenekleri}

Gebeliğin erken döneminde teşhis edilen primer maternal CMV ile ilişkili prognozun zayıf olması nedeniyle, gebeliği isteğe bağı sonlandırma seçeneği tartışmalıdır. Gebeliğe devam etmek isteyen kadınlara çeşitli tıbbi tedavilerden biri önerilebilir; ancak, bunların hepsi hala araştırma aşamasında olan yaklaşımlardı ${ }^{50,51}$. Semptomatik enfeksiyonlu yenidoğanların tedavisinde IV gansiklovir ve oral valgansiklovir çalışılmışır ${ }^{2}$. Semptomatik yenidoğanlarda, altı haftalık bir IV gansiklovir tedavisinin, bazı yenidoğanlarda görülebilecek nötropeniye rağmen, işitme kaybı insidansını önemli ölçüde azalttı̆̆ı bildirilmiş$\operatorname{tir}^{2,37}$. Semptomatik bebeklerde oral valgansiklovir ile yapılan antiviral tedavinin, işitme ve nörogelişimsel sonuçları iyileştirdiği gösterilmiştir ${ }^{2,37,53}$. Ek olarak, valgansiklovir tedavisi ile ilişkili nötropeni insidansının, IV gansiklovir tedavisi alan hastalara göre daha düşük olduğu bildirilmiştii ${ }^{52}$. Gebelikte $\mathrm{CMV}$ tedavisinde antiviral ajanların güvenliğini ve etkinliğini belirlemek için daha ileri çalışmaların gerekli olduğu belirtilmektedir²,14. Bu nedenle, günümüzde orta dereceli ve ciddi semptomatik bulguları olan doğumsal enfekte yenidoğanlara altı ay boyunca valgansiklovir tedavisi önerilirken, asemptomatik veya hafif semptomatik konjenital CMV enfeksiyonu olan yenidoğanlar için yan etkileri ve toksisitesi dolayısıyla antiviral tedavi önerilmemektedir ${ }^{2}$. Ayrıca, tedavi süresinin altı ayı geçmemesi ve bebeklerin nötropeni riski açııından takip edilmesi önerilmektedir².

In vitro ve in vivo hayvan çalışmaları, CMV HIG tedavisinin, CMV enfeksiyonunun neden olduğu hasarı en aza indirmede etkili olabileceğini göstermiştir ${ }^{2,14,51}$. Günümüzde yüksek titreli ve avidite indeksi yüksek anti-CMV antikorları olan seçilmiş donörlerin plazmasından üretilen HIG ürünleri ticari olarak kullanıma sunulmuştur ${ }^{51}$. Bir çalışmada tedavi almamıs annelerle kıyaslandığında, gebeliğinin 20-24. haftalarında IV HIG ile tedavi edilen kadınlardan doğan bebeklerin bir yaşında olumsuz klinik duruma sahip olma oranının daha düşük olduğu gösterilmiştii ${ }^{54}$. Gebelik döneminde erken gebelikten başla- 
yarak çoklu HIG uygulamasının, gebelik süresinde kısalma veya azalan doğum ağırlığıyla ilişkili olmadığı ve kullanımının güvenli olduğu bildirilmiştir ${ }^{50}$. HIG tedavisi etkinliğinin değerlendirildiği çalışmalarda tedavinin yararlarına yönelik bazı kanıtlar sunulmuş olsa da, genel olarak bu çalışmaların sonuçları kesin bir bilgi sunmamıştır ve bu nedenle daha fazla veri mevcut olana kadar primer enfeksiyonu olan gebelerde fetal enfeksiyonunu önlemek için veya enfekte fetüslerin tedavisinde CMV HIG tedavisinin rutin uygulaması önerilmemektedir ${ }^{2}$. Bununla birlikte, konjenital CMV uyumlu ultrasonografik bulguları olan veya amniyotik sıvıda CMV saptanan hastalara HIG tedavisinin seçenek olarak kullanılabileceği ve bu tedavinin yararları hakkında ebeveynlere bilgi verilmesi önerilmektedir ${ }^{51}$.

Konjenital CMV enfeksiyonları ile ilişkili olumsuz sonuçların güncel durumuna ait tahminlerin yapılabilmesi için hastalığının gerçek yükü konusundaki farkındalığın artması, halk sağlığı kaynaklarının tahsisi ve potansiyel girişimlerin maliyet-etkinliğinin belirlenmesi gerekmektedir. Sensörinöral işitme kaybı ve gelişimsel gecikmelere erken müdahaleyi mümkün kıldığı için enfekte bebeklerin yenidoğan tarama testleri ile erken dönemde saptanması kritik öneme sahiptir. Gebelik öncesinde CMV seropozitifliği olan bağışık annelerden doğan çocuklarda da semptomatik enfeksiyonlar gelişebilmekte ve bu durum maternal immünitenin bebeği korumada yetersiz kalabileceğini göstermektedir. Sekonder enfeksiyonlara bağlı konjenital CMV sıklığı ülkemizde ve birçok ülkede primer enfeksiyonlardan daha fazla görülmektedir. Rutin tarama sırasında işitme kaybı saptanan bebeklerde konjenital CMV değerlendirmesi de (hedefli tarama) yapılmalıdır. Asemptomatik enfekte bebeklerin de uzun dönem sekel riski altında olması dikkate alındığında, annenin serolojik durumuna bakılmaksızın tüm yenidoğanların CMV DNA testleri ile rutin tarama programları kapsamında taranması (universal tarama) önem arz etmektedir. Görülme sıklığı, tanı ve tedavi olanaklarının varlığı ve olumsuz etkilerinin önlenebilir/azaltılabilir olması ile rutin yenidoğan tarama testleri arasında yer alması geren konjenital CMV'nin tarama programlarına dahil edilmesinin önündeki en önemli engel maliyet sorunu iken, son dönemde yapılan çalışmalarda yenidoğan CMV taramasının uzun dönemde sağladığı kamu yararı ve tasarruf ile maliyet-etkin bir uygulama olduğu gösterilmiştir ${ }^{44,55-57}$.

\section{ÇIKAR ÇATIŞMASI}

Yazar bu makale ile ilgili herhangi bir çıkar çatışması bildirmemiştir.

\section{KAYNAKLAR}

1. Sahiner F, Cekmez F, Cetinkaya M, Kaya G, Kalayci T, Gunes O, et al. Congenital cytomegalovirus infections and glycoprotein B genotypes in live-born infants: a prevalence study in Turkey. Infect Dis (Lond) 2015;47(7):465-71.

2. Coleman JL, Steele RW. Preventing congenital cytomegalovirus infection. Clin Pediatr (Phila) 2017;56(12):1085-94.

3. Zuhair M, Smit GSA, Wallis G, Jabbar F, Smith C, Devleesschauwer B, et al. Estimation of the worldwide seroprevalence of cytomegalovirus: a systematic review and meta-analysis. Rev Med Virol 2019;29(3):e2034.

4. Manicklal S, Emery VC, Lazzarotto T, Boppana SB, Gupta RK. The "silent" global burden of congenital cytomegalovirus. Clin Microbiol Rev 2013;26(1):86-102. 
5. Cannon MJ, Hyde TB, Schmid DS. Review of cytomegalovirus shedding in bodily fluids and relevance to congenital cytomegalovirus infection. Rev Med Virol 2011;21(4):240-55.

6. Boppana SB. Cytomegalovirus, pp: 73-86. In: Hutto C (ed), Congenital and Perinatal Infections. 2006, Humana Press Inc, Totowa, NJ, USA.

7. Eren Dağlar D, Öngüt G, Çolak D, Özkul A, Mutlu D, Zeytinoğlu A, et al. Türkiye'de farklı coğrafi bölgelerde ve farklı hasta gruplarındaki sitomegalovirus izolatlarının glikoprotein B genotiplerinin belirlenmesi. Mikrobiyol Bul 2016;50(1):53-62.

8. Permar SR, Schleiss MR, Plotkin SA. Advancing our understanding of protective maternal immunity as a guide for development of vaccines to reduce congenital cytomegalovirus infections. J Virol 2018;92(7). pii: e00030-18.

9. Schoenfisch AL, Dollard SC, Amin M, Gardner LI, Klein RS, Mayer K, et al. Cytomegalovirus (CMV) shedding is highly correlated with markers of immunosuppression in CMV-seropositive women. J Med Microbiol 2011;60(Pt 6):768-74.

10. Pereira L, Tabata T, Petitt M, Fang-Hoover J. Congenital cytomegalovirus infection undermines early development and functions of the human placenta. Placenta 2017;59(Suppl 1):S8-16.

11. Kenneson A, Cannon MJ. Review and meta-analysis of the epidemiology of congenital cytomegalovirus (CMV) infection. Rev Med Virol 2007;17(4):253-76.

12. Townsend CL, Forsgren M, Ahlfors K, Ivarsson SA, Tookey PA, Peckham CS. Long-term outcomes of congenital cytomegalovirus infection in Sweden and the United Kingdom. Clin Infect Dis 2013;56(9):12329.

13. Fowler KB, Boppana SB. Congenital cytomegalovirus infection. Semin Perinatol 2018;42(3):149-54.

14. Carlson A, Norwitz ER, Stiller RJ. Cytomegalovirus infection in pregnancy: should all women be screened? Rev Obstet Gynecol 2010;3(4):172-9.

15. Satılmış A, Güra A, Ongun H, Mendilcioğlu I, Çolak D, Oygür N. CMV seroconversion in pregnants and the incidence of congenital CMV infection. Turk J Pediatr 2007;49(1):30-6.

16. Aynioglu A, Aynioglu O, Altunok ES. Seroprevalence of Toxoplasma gondii, rubella and cytomegalovirus among pregnant females in north-western Turkey. Acta Clinica Belgica 2015;70(5):321-4.

17. Sert $Y$, Ozgu Erdinc AS, Saygan S, Engin Ustun Y. Antenatal cytomegalovirus infection screening results of 32,188 patients in a tertiary referral center: a retrospective cohort study. Fetal and Pediatric Pathology 2019;38(2):112-20.

18. Uysal A, Taner CE, Cüce M, Atalay S, Göl B, Köse S, et al. Cytomegalovirus and rubella seroprevalence in pregnant women in Izmir/Turkey: follow-up and results of pregnancy outcome. Arch Gynecol Obstet 2012;286(3):605-8.

19. Parlak M, Çim N, Erdin BN, Güven A, Bayram Y, Yıldızhan R. Seroprevalence of Toxoplasma, rubella, and cytomegalovirus among pregnant women in Van. Turk J Obstet Gynecol 2015;12(2):79-82.

20. Özdemir M, Esenkaya Taşbent F, Terzi HA, Çetinkol Y, Uysal EB, Aşık G, et al. Seroprevalence of major viral pathogens during pregnancy: a multicenter study in Turkey. Adv Clin Med Microbiol 2016;1(1):1-5.

21. Şahiner F, Honca M, Çekmez Y, Kubar A, Honca T, Fidancı MK, et al. The role of maternal screening in diagnosing congenital cytomegalovirus infections in highly immune populations. Ir J Med Sci 2015;184(2):475-81.

22. Sirin MC, Agus N, Yilmaz N, Bayram A, Derici YK, Samlioglu P, et al. Seroprevalence of Toxoplasma gondii, rubella virus and cytomegalovirus among pregnant women and the importance of avidity assays. Saudi Med J 2017;38(7):727-32.

23. Altunal LN, Esen AB, Karagöz G, Yaşar KK. Seroprevalence of Toxoplasma gondii, rubella, and cytomegalovirus among pregnant refugees and Turkish women: a retrospective comparative study. South Clin Ist Euras 2018;29(4):235-9.

24. Akercan F, Zeybek B, Tavmergen Goker EN, Karadadas N. Maternal primary CMV infection with fetal transmission. Ege Tıp Dergisi 2011;50(4):261-3. 
25. Dogan Y, Yuksel A, Kalelioglu IH, Has R, Tatli B, Yildirim A. Intracranial ultrasound abnormalities and fetal cytomegalovirus infection: report of 8 cases and review of the literature. Fetal Diagn Ther 2011;30(2):141-9.

26. Kirimi E, Peker E, Tuncer O, Ozkan M, Ozmen B, Ceylan A. DNA-positive, IgM-negative symptomatic congenital cytomegalovirus infection: two case reports. J Matern Fetal Neonatal Med 2010;23(7):725-7.

27. Ünal S, Işık DU, Güral G, Arifoğlu i, Özcan Ç, Bas AY, et al. Konjenital CMV enfeksiyonun prematürelerde nadir görülen santral sinir sistemi bulgusu: nöronal migrasyon anomalisi. Türkiye Çocuk Hastalıkları Dergisi 2017;12(3):218-20.

28. Zeytinoğlu A, Terek D, Arslan A, Erensoy S, Altun Köroğlu Ö, Bozdemir T, et al. Yenidoğan bebeklerin tükürük örneğinde CMV DNA varlığı ile konjenital CMV enfeksiyonunun araştırılması. Mikrobiyol Bul 2019;53(1):53-60.

29. Luck SE, Emery VC, Atkinson C, Sharland M, Griffiths PD. Compartmentalized dynamics of cytomegalovirus replication in treated congenital infection. J Clin Virol 2016;82:152-8.

30. Britt WJ. Congenital human cytomegalovirus infection and the enigma of maternal immunity. J Virol 2017;91(15). pii: e02392-16.

31. Prince HE, Lapé-Nixon M. Role of cytomegalovirus (CMV) lgG avidity testing in diagnosing primary CMV infection during pregnancy. Clin Vaccine Immunol 2014;21(10):1377-84.

32. Fornara C, Furione M, Lilleri D, Cane I, Revello MG, Zavattoni M, et al. Primary human cytomegalovirus infections: kinetics of ELISA-IgG and neutralizing antibody in pauci/asymptomatic pregnant women vs symptomatic non-pregnant subjects. J Clin Virol 2015;64:45-51.

33. Stagno S, Reynolds D, Tsiantos A, Fuccillo DA, Smith R, Tiller M, et al. Cervical cytomegalovirus excretion in pregnant and nonpregnant women: suppression in early gestation. J Infect Dis 1975;131(5):522-7.

34. Shen CY, Chang SF, Yen MS, Ng HT, Huang ES, Wu CW. Cytomegalovirus excretion in pregnant and nonpregnant women. J Clin Microbiol 1993;31(6):1635-6.

35. Leyder M, Vorsselmans A, Done E, Van Berkel K, Faron G, Foulon I, et al. Primary maternal cytomegalovirus infections: accuracy of fetal ultrasound for predicting sequelae in offspring. Am J Obstet Gynecol 2016;215(5):638.e1-8.

36. Tanimura K, Yamada H. Maternal and neonatal screening methods for congenital cytomegalovirus infection. J Obstet Gynaecol Res 2019;45(3):514-21.

37. Luck SE, Wieringa JW, Blázquez-Gamero D, Henneke P, Schuster K, Butler K, et al. Congenital cytomegalovirus: a European expert consensus statement on diagnosis and management. Pediatr Infect Dis J 2017;36(12):1205-13.

38. Delforge ML, Costa E, Brancart F, Goldman D, Montesinos I, Zaytouni S, et al. Presence of cytomegalovirus in urine and blood of pregnant women with primary infection might be associated with fetal infection. J Clin Virol 2017;90:14-7.

39. Koyano S, Inoue N, Nagamori T, Moriuchi H, Azuma H. Newborn screening of congenital cytomegalovirus infection using saliva can be influenced by breast feeding. Arch Dis Child Fetal Neonatal Ed 2013;98(2):F182.

40. Sorichetti B, Goshen O, Pauwels J, Kozak FK, Tilley P, Krajden M, et al. Symptomatic congenital cytomegalovirus infection is underdiagnosed in British Columbia. J Pediatr 2016;169:316-7.

41. Forner G, Abate D, Mengoli C, Palù G, Gussetti N. High cytomegalovirus (CMV) DNAemia predicts CMV sequelae in asymptomatic congenitally infected newborns born to women with primary infection during pregnancy. J Infect Dis 2015;212(1):67-71.

42. Özdemir ÖMA, Tümkaya F. Yenidoğanda işitme tarama programı ve yönetimi. Turkiye Klinikleri J Pediatr 2017;26(1):13-21.

43. Turan Z. Yenidoğan işitme tarama programlarının işitme kaybının tanı, cihazlanma ve eğitime başlama yaşına etkisi. Abant İzzet Baysal Üniversitesi Eğitim Fakültesi Dergisi 2018;18(2):1156-74.

44. Hilditch C, Liersch B, Spurrier N, Callander E, Cooper C, Keir AK. Does screening for congenital cytomegalovirus at birth improve longer term hearing outcomes? Arch Dis Child 2018;103(10):988-92.

45. American Fertility Society. New guidelines for the use of semen donor insemination. Fertil Steril 1990;53(S1):1-7. 
46. Marsico C, Kimberlin DW. Congenital cytomegalovirus infection: advances and challenges in diagnosis, prevention and treatment. Ital J Pediatr 2017;43(1):38.

47. Adler SP. Immunization to prevent congenital cytomegalovirus infection. Br Med Bull 2013;107:57-68.

48. Dasari V, Smith C, Khanna R. Recent advances in designing an effective vaccine to prevent cytomegalovirusassociated clinical diseases. Expert Rev Vaccines 2013;12(6):661-76.

49. Bernstein DI, Munoz FM, Callahan ST, Rupp R, Wootton SH, Edwards KM, et al. Safety and efficacy of a cytomegalovirus glycoprotein $\mathrm{B}(\mathrm{gB})$ vaccine in adolescent girls: a randomized clinical trial. Vaccine 2016;34(3):313-9.

50. Nigro G, Capretti I, Manganello AM, Best AM, Adler SP. Primary maternal cytomegalovirus infections during pregnancy: association of CMV hyperimmune globulin with gestational age at birth and birth weight. J Matern Fetal Neonatal Med 2015;28(2):168-71.

51. Nigro G. Hyperimmune globulin in pregnancy for the prevention of congenital cytomegalovirus disease. Expert Rev Anti Infect Ther 2017;15(11):977-86.

52. Kimberlin DW, Jester PM, Sanchez PJ, Ahmed A, Arav-Boger R, Michaels MG, et al. Valganciclovir for symptomatic congenital cytomegalovirus disease. N Engl J Med 2015;372(10):933-43.

53. James SH, Kimberlin DW. Advances in the prevention and treatment of congenital cytomegalovirus infection. Curr Opin Pediatr 2016;28(1):81-5.

54. Visentin S, Manara R, Milanese L, Da Roit A, Forner G, Salviato E, et al. Early primary CMV infection in pregnancy: maternal hyperimmune globulin therapy improves children's outcome at one year. Clin Infect Dis 2012;55(4):497-503.

55. Williams EJ, Gray J, Luck S, Atkinson C, Embleton ND, Kadambari S, et al. First estimates of the potential cost and cost saving of protecting childhood hearing from damage caused by congenital CMV infection. Arch Dis Child Fetal Neonatal Ed 2015;100(6):F501-6.

56. Bergevin A, Zick CD, McVicar SB, Park AH. Costbenefit analysis of targeted hearing directed early testing for congenital cytomegalovirus infection. Int J Pediatr Otorhinolaryngol 2015;79(12):2090-3.

57. Gantt S, Dionne F, Kozak FK, Goshen O, Goldfarb DM, Park AH, et al. Cost-effectiveness of universal and targeted newborn screening for congenital cytomegalovirus infection. JAMA Pediatr 2016;1 70(12):1173-80. 